doi: 10.14267/cojourn.2019v4n2a3

\title{
Constructing the Borderland: The Legacy of Versailles and the Small States of Central Europe
}

\author{
Zoltán Kelemen and Máté Szalai ${ }^{1}$
}

\begin{abstract}
The paper seeks to interpret the unique nature of the Central European region as a borderland of the Western society of states, a status which developed throughout history but crystallized most clearly as a result of the Versailles peace treaties. We track this process through understanding the specific route of Central European state formation by juxtaposing the impact of two key periods of early modern intellectual evolution on the region. Pointing to the belatedness of absolutistic centralisation and the timely arrival of nationalism in Central Europe, we show how the latter dismantled the more heterogeneous and centralised states of the region. Following this, the consequences of the Versailles Treaties are evaluated with a focus on the self-perceived image of the new countries and the role of intellectuals.
\end{abstract}

Keywords: enlightenment, Versailles, Central Europe, small states, borderland

The peace treaties of Versailles represented the beginning of the modern history of Central Europe. At the end of World War I, the multi-ethnic empires of the region dissolved, paving the way for the emergence of small nation-states. Nonetheless, due to the differences between the Western and Central European political and social reality, the political communities of the region have not fully integrated into the Western international society - they seemingly mirrored its fundamental institutions but with very different internal dynamics. Thus, retrospectively, the main legacy of Versailles is the creation of the fragmented Central European borderland, consisting of small states.

\footnotetext{
${ }^{1}$ Máté Szalai and Zoltán Kelemen are both Assistant Lecturers at Corvinus University of Budapest. Additionally, Máté Szalai is Research Fellow and program coordinator at the Institute for Foreign Affairs and Trade. Zoltán Kelemen is Academic and Pedagogical Director at Saint Ignatius Jesuit College.
} 
doi: 10.14267/cojourn.2019v4n2a3

The concept of borderlands is a quite complex and multi-layered one. It represents a social space in "a given territory (...) permanently populated by the representatives of two or more social groups, which are having distinctive, separate cultures of their own or their autonomous parts, which are most of all treated as separate in the social consciousness" (Sadowski, 2009: 83). Due to the spatial closeness of at least one boundary, the political and social relations of borderlands are shaped excessively by the existence of such borders (be they of any nature), albeit not necessarily in a conflictual way. Naturally, borderlands exist in all countries - in the framework of this study, based on Sadowski's approach, we will refer to Central Europe as a civilisational borderland or systemic borderland, namely as a region of "historically changing" nature, "located between the discussed civilizations' territory with a specific concentration of historical, ethnic, religious, political, language and other borders. These borders constitute an active cultural "equipment" of the inhabitants (being a component of the contemporary consciousness and the social memory of the inhabitants of the given territory) and help to realize the social processes of inclusion and exclusion" (Sadowski, 2009: 88).

Based on this definition, one can argue that Central Europe is clearly a civilisational borderland of the Western political and cultural community, standing between the core area of the West on the one hand and Orthodox civilisation and the former Ottoman sphere on the other. In this sense, its peoples find themselves in a rather unique situation, characterised by relative weakness, between major powers, political belonging to the West but without a complete integration into its political and cultural space. The article has two goals - firstly, to describe the historical processes which led to the establishment of this borderland, in which Versailles represented a cornerstone, and secondly to outline the basic nature of the Central European borderland.

The perception of the borderland status (both inside and outside of the region) has been heavily shaped by the differences of size between Western and Eastern European countries, where we understand "size" as a comprehensive measure of assets (such as territory), capacities and capabilities altogether. Even though small states also exist in Western Europe, the region is characterised by states of comparatively greater territory, population, economic output and military capabilities, while comparable big states are rather exceptions to the rule in Central Europe. We will try to detect some of the reasons for the birth of the small states of Central Europe by juxtaposing the ways in which two major streams of modernity have influenced this region compared to Western Europe. To that end, we need to look at two key periods of the formation of modern European nation- 
doi: 10.14267/cojourn.2019v4n2a3

states, those of Classical Europe and the Enlightenment. The former contributed to the birth of modern Westphalian statehood in the $17^{\text {th }}$ century, while the latter triggered the awakening of nations in the $18^{\text {th }}$ century and the rise of nationalism in the $19^{\text {th }}$ century. We will attempt to identify the extent to which these periods and their streams of thought influenced the Central European region.

\section{Classical Europe}

If we were to draw a circle centred around Paris with a radius of 1,000 kilometres we would get the geographic reach of Classical Europe according to Pierre Chaunu (Chaunu, 1966: 279). Classical Europe signifies the period around the $17^{\text {th }}$ and early $18^{\text {th }}$ centuries when the preconditions of the Enlightenment were created. It is a period of unheard-of social and scientific progress. It is characterised by Philippe Ariès as the era when when socially active roles were prolonged into an older age thanks to the growing relevance of intellectual work (Ariès, 1987:319-351), with physical work no longer being the exclusive way of personally contributing to society. New technological achievements certainly resulted in a significant increase in the quality of life and, as a consequence, also in a positive change of average life expectancy. In terms of academic achievements, it is worth noting that Chaunu found the period of classical Europe comparable only to the period of $4^{\text {th }}$ century BC and the years between 1898 (Max Planck's Quanta) and 1914 (Einstein's general theory of relativity). The academic pinnacle of classical Europe is best reflected by Descartes' Discours de la méthode and Newton's Principia Philosophiae. Written in 1637 and 1687, respectively, these works provided the basis for modern academic thought (Chaunu, 1966: 22). Knowledge production would be fundamentally transformed as a result of these works within the sphere of Classical Europe, and this would pose a significant long-term challenge of catching up for the regions missing out on this development at the time.

Classical Europe gave birth to academies of sciences, stock exchanges and the modern concept of art. And, perhaps most important of all, ingredients of modern statehood all appeared during these decades. Schooling and obligatory military service were a major innovation of classical European absolutism. By moving a considerable share of the population from one part of the country to another with the introduction of universal conscription, the classical state put its society on the track of homogenisation. We are talking of an era when the efficiency of the state reached unprecedented levels and when what we call Westphalian international order was gradually taking shape. 
doi: 10.14267/cojourn.2019v4n2a3

It is not irrelevant therefore to take a closer look at how Western and Central Europe related to the civilization of classical Europe because, as we will see, those countries where the state started the process of absolutistic centralisation belatedly would have to face the awakening of nations as a threat to their territorial integrity. In terms of the region in our focus, an ambiguous picture emerges. While some parts of Central Europe, such as Bohemia or today's territory of Slovenia, clearly fall within the circle drawn by Chaunu, others found themselves outside of it. The best indicator of the borders of classical Europe is the time/distance function. While the function measured from Paris remains linear between 50 and 1,000 kilometres, it bends in the shape of a parabola above 1,000 kilometres. From thereon, adding but 500 kilometres essentially means the doubling of travelling time. Thus, in terms of time, the journey between Paris and Cádiz is equal to two such journeys travelling from Paris to Madrid; Paris-Messina corresponded to two journeys from Paris to Rome while one Paris-Buda trip equalled two Paris-Vienna journeys (Chaunu, 1966:279). ${ }^{2}$ This law considerably influenced the flow of people, goods, inventions and above all, ideas. It is no wonder therefore that the concept of modern statehood and its earliest manifestation in the form of absolutism were so frequent within that circle and so rare outside of it in the $17^{\text {th }}$ century.

At the time when absolutistic state design swept across Europe from France to Spain and the German principalities, the two major historical states of Central Europe went mostly untouched by this trend. In Perry Anderson's words, Poland provided "a graphic a contrario demonstration of the historical rationality of Absolutism" (Anderson, 1979: 279). Poland was perhaps the only country of Europe that avoided absolutism not simply by abstaining from centralisation but by downright creating the first territorial republic of modern Europe. Within such frameworks, aristocratic individualism and the liberum veto jointly contributed to the partition of Poland which, juxtaposed to the rise of Prussian absolutism, amounts to a fitting illustration of the borders of Classical Europe (Anderson, 1979:279-296). Hungary was just becoming freed from Ottoman occupation towards the end of the period of Classical Europe and therefore the appearance of absolutistic statecraft was also belated there. In both of these places a moderated but foreign-imposed (by Russia and Austria, respectively) enlightened absolutism came into

\footnotetext{
${ }^{2}$ In fact, Chaunu mistakenly wrote Budapest instead of Buda, but his point is clear: „Loi de la distance ajoutée: de 50 à 1000 kilometres, la fonction temps/distance est, toutes choses étant égales (en fait, elle ne le sont jamais) linéaire. Au-delà, la droite s'incurve sur le bas en forme de parabole. Ajouter 500 kilometres à 1000 kilometres, c'est doubler en gros le temps de parcours: 1 Paris-Cadix = 2 Paris-Madrid, 1 ParisMessine = 2 Paris-Rome, 1 Paris-Budapest = 2 Paris-Vienne."
} 
doi: 10.14267/cojourn.2019v4n2a3

being in the $18^{\text {th }}$ century. Enlightenment thus started to influence the region without the stable basis of classical independent statecraft.

\section{Enlightenment, modernisation and nationalism}

Pierre Chaunu used a different borderline when he identified the Eastern limits of enlightened Europe in his La civilisation de l'Europe des lumières. Enlightened Europe was to be found to the West of the line connecting the Baltic and the Black Seas. That was the area where 90 or 95 percent of the society would have birth, marriage and death certificates already between 1680 and 1780 (Chaunu, 1971:113). It is worth noting that while the civilization of classical Europe only featured some territories of Central Europe, Enlightenment seems to have affected most of it. The most spectacular illustration of Enlightenment could be the growing relevance of literacy, which made linguistic reform an important vehicle of national identity-building. The transformative power of literacy and philology brought to life a horizontal form of consciousness, that of the modern nation (Geary, 2014:43-49). ${ }^{3}$ In Anthony D. Smith's view, the term 'nationalism', with its modern connotation, can be traced back to the work of one of the most influential German enlightened philosophers, Herder, but it spread onward only in the $19^{\text {th }}$ century (Smith, 1983:167). This time Central Europe was not lagging behind and was simultaneously influenced by the rise of the new ideology, as reflected by the waves of linguistic reforms and the awakening of nations in the $18^{\text {th }}$ and $19^{\text {th }}$ centuries (Geary, 2014:43-49).

The size of modern European states was also shaped by modernisation and nationalism. "Pressures and constraints of development", argues Thomas Nairn (1997:144) "ensured that only entities above a certain threshold of scale" had the ability to survive in the anarchic interstate environment. The optimal model for the new era was that of France, surpassing the "confines of the city-state" and the "bureaucratic hierarchies of the ancient empire-state" (ibid: 147), because it was "capable of constructing a distinguishable political economy of its own, the range of cultural and administrative institutions needed for managing this, and an army capable of defending it” (ibid: 133). Thus, the heritage of modernisation and nationalism includes the comparatively big states of Western Europe.

\footnotetext{
${ }^{3}$ Geary treats here modern philology as a root cause of the idea of the homogenous nation-state.
} 
doi: 10.14267/cojourn.2019v4n2a3

\section{Fragmentation}

As we have seen, Central Europe was not an integral part of Classical Europe and thus it was only partially affected by modern absolutism in the $17^{\text {th }}$ century. However, it was almost fully integrated into enlightened Europe, and therefore the ideology of nationalism arrived on time in the $18^{\text {th }}$ and $19^{\text {th }}$ centuries. The region had to face the temptations of national awakening without the long-term unifying and homogenising impact of absolutistic statecraft. While the various regions of France, the cities and the countryside could speak the same literary language by the $19^{\text {th }}$ century when nationalism hit in, Central Europe could be characterised by multilingual, multi-ethnic and fragmented societies where cities, the countryside and various regions of the state spoke different languages up until the early $20^{\text {th }}$ century ${ }^{4}$ (Geary, 2014:52-53).

It was this state of affairs in which the countries of the region had to deal with the awakening of nations. Nationalism preceding independent modern statehood resulted in national communities built up on the basis of linguistic and ethnic differences, not on political or economic realities (Bibó, 2011), creating a fractured mosaic in the region. It is hardly surprising, therefore, that with the rise of the principle of the self-determination of peoples, World War I left behind much fragmentation in this region where homogenisation and consolidation of the nation-states could only take place on smaller territories.

\section{The legacy of Versailles and the establishment of the Central European borderland} As a result of the above-mentioned circumstances in Central Europe, the creation of a comprehensive state system based on respect for demands of self-determination was unimaginable at the end of World War I. Allied powers did arrive at the same conclusion, and they did not in fact seek to set this impossible norm for the newly created "nations." Poland was the first territory where national self-determination was designated as a fundamental norm to be respected (Halecki, 1982: 398). In the case of the peoples of Austria-Hungary, President Wilson himself supported solely the "the freest opportunity of autonomous development" (Halecki, 1982: 399). Even in the case of the Russian empire, the U.S. administration did not push for the self-determination of all nations. Naturally, the different treatment was a result of geopolitical considerations.

\footnotetext{
${ }^{4}$ This only changed with the deportations of the 20th century.
} 
doi: 10.14267/cojourn.2019v4n2a3

It was not only the creation of the Versailles system which (re)produced the Central European borderland, but many other historical developments also contributed to its emergence - first and foremost the establishment of communist regimes in the region without a complete integration into the Soviet Union. However, the Versailles system was historically the first major step in constructing Central Europe as a politically separate spatial unit. While the peace treaties formally integrated Central European states into the European state system, many of their consequences had long-lasting effects which shape regional politics even today.

First, Central Europe became a region of small states which are painfully aware of their size. While Versailles provided independence for many of Central Europe's nations, it deprived them of the security architecture offered by the Austro-Hungarian Monarchy. The ideas of Czech historian František Palacký summarise the situation perfectly - he argued that the Monarchy should not have been abolished since it protected Central European nations from the "hegemony of great powers" (Kazharski, 2019:3); rather, it should have been internally reformed. As a result, the legacy of Versailles is not just national independence but also a sense of exposure and weakness. In the words of Tomáš Masaryk, "we must bear in mind, that we are a small people in an unfavourable geographical position" (ibid).

The second legacy of the peace treaties is that the notions of "nation" and "territoriality", as cornerstones of the Westphalian international system, were attributed a different meaning in the region, which impacts on geopolitical and foreign policy thinking to this day. After Versailles, the borders between states and nations do not overlap, questioning the basic functioning of "nation-states". Many communities found themselves in the "wrong state", namely where the majority represents a different political-ethnic group (Roter, 2012:183), a status which they did not manage to accept. As a result, the official boundaries of countries are perceived to have a "variable geometry" (Babeti cited by Nikiforova, 2012:104), which means that they are more imaginary and less solid, and they are constantly in the process of reconstruction in response to the changes of the historical and political context (Nikiforova 2012:105). Moreover, due to this mosaic of national communities being present in almost each state, nation-building has often contradicted democratic norms (Drulák, 2012: 31), leading to a more exclusive interpretation of nationalism.

Thirdly, state identities in Central Europe developed in a very diverse manner. According to Petra Roter (2012: 183), "some have unfulfilled ambitions (Poland), some 
doi: 10.14267/cojourn.2019v4n2a3

are traumatized by their losses (Hungary), and others suffer from historical inferiority complexes and fears (Slovakia and the Czech Republic [and Slovenia])". Differences in identity also include the altered perception of one's own size or the interpretation of coreperiphery relations in Europe (Kazharski, 2019). This not only complicates interstate relations, but also makes foreign policy in the region less predictable, more diverse and less suitable for analysis using (only) Western IR theories as a framework.

Fourth, this being a point relevant specifically to Hungary's case, Versailles strengthened the unique experience and identity of the Hungarian political elite. From a comparative point of view, the Treaty of Trianon (which set the modern borders of Hungary) with all its controversies did not really constitute such an unambiguous case of mistreatment as it is often argued in Hungary. Almost all of the communities concerned perceived at least some of the newly created borders as unjust. The particularity of the Hungarian experience derived from the previously held strong position in the AustroHungarian Empire, in what was formerly one of the largest states of Europe. In the system created by the 1867 Compromise, the Hungarian elite participated in the foreign policy decision-making of the Empire. This was the environment in which the socialization of the elite took place. While "foreign policy was the prerogative of the emperor", as S. Wank argues (1967: 41), it "had to be brought into harmony with the interests of both the Magyars [Hungarians] and the Germans". Through narrow institutional and somewhat wider informal and personal ways, the Hungarian elite took part in forming the common foreign policy, even if it played a limited or inferior role in this respect (Szijártó, 1994).

The experience of participating in the foreign policy-making of a large empire was absent in the case of almost all of the newly created Central European nations. ${ }^{5}$ On the eve of World War I, there was not even an independent nation-state besides Romania in the north of the Balkans. It is only from this perspective that we can understand the true effects of the Treaty of Trianon on Hungary - this impact entailed not only the loss of ethnic-Hungarian territories but also the loss of former grandeur. As a result, the Hungarian elite and society have been struggling to deal with the difference between the actual and the desired (and remembered) size and power of the country (Szalai, 2018).

Fifth, Versailles strengthened the uniqueness of how knowledge production is conducted in Central Europe, especially in the social sciences (Drulák, 2012), which contributes to the reproduction of the alterations of the previously described uniqueness

\footnotetext{
${ }^{5}$ The exception can be the Czech elite, which also participated in the monarchic foreign policy, although to a much narrower extent than Hungarians.
} 
doi: 10.14267/cojourn.2019v4n2a3

of the region. After the age of Enlightenment, Western societies differentiated between practitioners (in this case, politicians) on the one hand, and scientists on the other. The job of the latter was to monitor, evaluate and criticize practical developments. Even if they intervened in politics (as during the French revolution), they constructed separate intellectual spheres. Central Europe was touched by the evolution of Western-style modern science already in the $19^{\text {th }}$ century, but went through a clear transformation in this respect. Due to the political and social realities of the region (especially the imperial system, the small size of national elites and the belated nation-building efforts), there was no clear line separating intellectuals and scientists as the latter group had to play a prominent role in their national communities. Moreover, as a result of the newly created states, post-Versailles, "the agenda of the intellectual idiom became much larger in the East as it not only reformed the state institutions but actually rebuilt these institutions from scratch" (Drulák, 2012:20). Such tendencies were strengthened by the Communist era during which the sciences were completely under state control. The result has been a more political and politically dependent scientific elite which is deeply embedded into state institutions and dependent on them for funding.

\section{Conclusion}

We attempted to uncover the role of Versailles in the formation of the Central European borderland. In doing so, we focused first on the rise of small states and explained it through the region's shifting place and character in two key periods of modern state formation, those of Classical Europe and the Enlightenment.Belatedness in absorbing absolutistic statecraft relative to Western Europe, and the appearance of nationalism simultaneously with its rise in the West, were interpreted as two determinants of the birth of Central European small states. With its unique historical development and political norms, the region produced a particular Central European IR political culture. The definitive attributes of this culture include the perception of smallness and weakness, the alterations of the norms of territoriality and nationhood, diverging state identities, and altered ways of knowledge production, all of which still effect political thinking in Central European countries. Versailles did not create the uniqueness of Central Europe but - by spreading the modern state system into the region without abolishing existing normative differences - it did construct the Central European borderland. 
doi: 10.14267/cojourn.2019v4n2a3

\section{References}

Anderson, Perry (1979): Lineages of the Absolutist State, Verso, London-New York .

Ariès, Philippe (1987): Gyermek, család, halál. Gondolat, Budapest.

Bibó, István (2011) : A kelet-európai kisállamok nyomorásúga. Augmentum, Budapest.

Chaunu, Pierre (1966): La Civilisation de l'Europe classique. Arthaud, Paris.

Chaunu, Pierre (1971) : La Civilisation de l'Europe des lumières. Arthaud, Paris.

Drulák, Petr (2012) : Central Europe and IR thinking : Traditions and disciplines. In: Zlatko Sabic - Petr Drulák (eds.) : Regional and International Relations of Central Europe. Palgrave MacMillan, New York, 18-39.

Geary, Patrick J. (2014) : A nemzetek mítosza, Atlantisz, Budapest.

Halecki, Oscar (1982): Borderlands of Western Civilization: A History of East Central Europe. Simon Publications, Safety Harbor.

Kazharski, Aliaksei (2019): Two kinds of small? The "EU core in Slovak and Czech geopolitical imagination. Journal of Contemporary European Studies.

Nikiforova, Basia (2012): Central Europe: Territoriality and Spiritual Images. Limes: Borderland Studies, 5/2, 103-114.

Roter, Petra (2012): Ethnic diversity management in Central Europe. In: Zlatko Sabic Petr Drulák (eds.) : Regional and International Relations of Central Europe. Palgrave MacMillan, New York, 181-200.

Sadowski, Andrzej (2009): The borderland of civilizations as a research category in the sociology of borderlands. LIMES: Cultural Regionalistics, 2/1, 82- 92.

Smith, Anthony D. (1983): Theories of Nationalism. Holmes \& Meyer Publishers, New York

Szalai, Máté (2017): The identity of smallness and its implications for foreign policy the case of Hungary and Slovakia. Journal of Contemporary Central and Eastern Europe, 25/3, 345-366.

Szijártó, I. M. (1994): Playing Second Fiddle. Scandinavian Journal of History, 19/2, 143163.

Wank, Solomon (1967): Foreign policy and the nationality problem in Austra-Hungary, 1867-1914. Austrian History Yearbook, 3/3, 37-56. 